\title{
アルミナ-W-BN 混合物を原料とする超高圧焼結体の破壊靯性
}

\author{
大竹一宏・野間 竜男・澤岡 昭 \\ (東京工業大学 工業材料研究所)
}

\begin{abstract}
アルミナーウルツ鉱型窒化ホウ素 $(\mathrm{w}-\mathrm{BN})$ 混合物の超高圧焼結を $6 \mathrm{GPa}, 1300^{\circ} \mathrm{C}$ で行い，その 密度, 硬さ, 破壊鞀性を測定し, X 線回折, 走查型電子顕微鏡観察を行った。 $\mathrm{w}-\mathrm{BN}$ の割合は 5 15 体積 \%とした. 超高圧焼結体を真空中, $1300^{\circ} \mathrm{C}$ で熱処理すると, $\mathrm{BN}$ は黒鉛類似構造へ転移し, 体積が $45 \%$ 増加した. 期待に反し，この熱処理によって焼結体の破壊勒性は著しく減少した．既 に報告したアルミナーダイヤモンド系では, 同様の熱処理によって破壊䩲性が増加する.この違いは, $\mathrm{BN}$ 系では真空中での $\mathrm{BN}$ の相転移が $600^{\circ} \sim 700^{\circ} \mathrm{C}$ で急激に起こり, 焼結体中にクラックが発生す るのに対し，ダイヤモンド系では $1300^{\circ} \mathrm{C}$ で相転移が徐々に進行し，局所的なクリープが起きて応 力が緩和され, クラック発生に至らないためと説明できる.

(1983 年 12 月 1 日受付)
\end{abstract}

\section{Fracture Toughness of High Pressure-Sintered Compacts Obtained from Mixture of Alumina and Wurtzite-Type Boron Nitride}

\author{
Kazuhiro OHTAKE, Tatsuo NOMA and Akira SAWAOKA \\ $\left(\begin{array}{l}\text { Research Laboratory of Engineering Materials, Tokyo Institute of Technology } \\ 4259, \text { Nagatsuta, Midori-ku, Yokohama-shi }\end{array} 227\right.$
}

\begin{abstract}
Wurtzite-type boron nitride (w-BN) was dispersed in alumina matrix and sintered under $6 \mathrm{GPa}$ and $1300^{\circ} \mathrm{C}$ for $60 \mathrm{~min}$. Density, hardness and fracture toughness were measured, and X-ray diffraction analysis and SEM observation were also conducted. Content of w-BN was 5-15 vol\%. Sintered compacts were heated at $10^{-3}$ Torr and $1300^{\circ} \mathrm{C}$ for 6 hours, and boron nitride was transformed into graphite like structure ( $\mathrm{g}-\mathrm{BN})$. Volume expansion was accompanied by the transformation. Fracture toughness of the heat-treated composites decreased. This was compared with the results of diamond-dispersed alumina ceramics. It is supposed that spontaneous microcracks propagated in the matrix, because the transformation temperature from w-BN into g-BN $\left(600^{\circ}-700^{\circ} \mathrm{C}\right)$ was too low for matrix alumina to relax the initiated stress due to the volume expansion. On the contrary, for diamond-alumina ceramics heat-treated in order to transform diamond into graphite, transformation temperature $\left(1300^{\circ} \mathrm{C}\right)$ was high enough for stress relaxation of the matrix.

[Received December 1, 1983]
\end{abstract}

Key-words : Fracture toughness, w-BN, Alumina, High pressure, Sintered body

\section{1. 緒言}

セラミックスの破壊靱性向上機構を解明するために, 著者らは先にアルミナーダイヤモンド混合物を出発原料 とする超高圧焼結体の勒性に関する研究を行った ${ }^{11}$. ダ イヤモンドが安定な圧力と温度の条件で得た複合焼結体 を真空中で加熱すると，アルミナ母相中に分散したダイ ヤモンドは黒鉛に転移し，この転移に伴って炭素の体積 は約 $45 \%$ 増加する。この体積膨張によってアルミナの
靶性は向上すると予想され, 実験結果も期待ぼおりで あった。この䩲性の向上は応力誘起微小クラック生成に よるものとして説明されている ${ }^{21}$.

アルミナーダイヤモンド系で見られた効果が，アルミ ナ-高圧型窒化ホウ素系でも生じるかどうか興味ある問 題である. 本報告は, ウルツ鉱型窒化ホウ素を添加した アルミナ焼結体の破壊勒性と微小硬さに関するものであ る. 


\section{2. 実 験}

メラー社製，粒径 $0.2 \sim 0.3 \mu \mathrm{m}$ ，純度 $99.98 \%$ の $\alpha$ アルミナと, 日本油脂製, 衝撃合成ウルツ鉱型 $\mathrm{w}-\mathrm{BN}$ (YPP) を出発原料として使用した. w-BN 粉末の粒 径は $0.1 \sim 0.5 \mu \mathrm{m}$ であり, 主な不純物は, 酸素, $\mathrm{Fe}$ (1000 ppm), Si (1000 ppm) である.

$\mathrm{w}-\mathrm{BN}$ が 5 体積 \%，10 体積 \%，15 体積\%になるよ うにひょう量後，アルミナボールミルを使用して，アル ミナと $\mathrm{w}-\mathrm{BN}$ を 24 時間エチルアルコール中で湿式混合 した. 室温で乾燥後, 混合物を $200 \mathrm{MPa}$ で成形した。 成形体を低圧型窒化ホウ素製スリーブに入れて $500^{\circ} \mathrm{C}$ で乾燥し, 超高圧焼結用カーボンヒーターに導入した。 超高圧焼結を行うため一辺が $16 \mathrm{~mm}$ の先端面を有する スライド式六方押し型アンビル装置を使用した。圧力媒 体として，一辺 $21 \mathrm{~mm}$ のパイロフィライト製立方体を 使用した。試料室の構成は別に報告したアルミナーダイ ヤモンド系の場合と同様である ${ }^{1)}$ 。焼結条件は，まず圧 力を $6 \mathrm{GPa}$ に上げ，次に温度を $1300^{\circ} \mathrm{C}$ に上昇させ 60 分保持した後，温度を下降させ，圧力を下げた。得られ た超高圧焼結体を更に $10^{-3}$ Torr の真空中, $1300^{\circ} \mathrm{C}$ で 熱処理した。この場合昇温に 3 時間かけ， $1300^{\circ} \mathrm{C} て ゙ 6$ 時間保った後, 12 時間かけて降温した。

粉末又は焼結体試料の $\mathrm{X}$ 線分析を，理学電機製 $\mathrm{X}$ 線 回折計 (2122 B 型, $\mathrm{CuK \alpha}, 35 \mathrm{kV}, 20 \mathrm{~mA}$ ) を使用し て行った.

粉末及び焼結体破面の観察には, 日本電子テクニクス 社製，JSM T-100 走査型電子顕微鏡を使用した。

微小硬さの測定には，明石製作所製微小ビッカース硬 度計 MVK-E 型を使用し, 測定荷重は $1 \mathrm{~kg}$ を使用した。 焼結体試料の平面研削を行った後, 粒度 $0.25 \mu \mathrm{m}$ のダ イヤモンドペーストによる平面研磨を行った。

試料が $6 \mathrm{~mm} \times 5.5 \mathrm{~mm} \phi$ と小さいため, 破壊靶性值 $K_{1 \mathrm{c}}$ はビッカース圧子押し込み法によって測定した。き 裂長さと $K_{1 \mathrm{c}}$ との間には, $(1)$ 式で表される関係が報 告されている3'.

$$
K_{\mathrm{lc}} \cdot\left(H_{\mathrm{v}} / E\right)^{1 / 2} / H_{\mathrm{v}} \cdot a^{1 / 2}=0.028(c / a)^{-3 / 2}
$$

$H_{\mathrm{v}}$ : ビッカース硬さ， $a$ : 圧痕対角線長の $1 / 2$,

$E$ : ヤング率, $c$ : き裂長さ

ここで, $H_{\mathrm{v}} / E$ の值は Marshall らによって求められた ヌープ圧子の長短対角線の比と $H_{\mathrm{v}} / E$ の関係式 $(2)$ 式を使用した 。

$$
H_{\mathrm{v}} / E=0.315-2.22(\beta / \alpha)
$$

$\alpha$ : ヌープ在痕の長対角線長さ， $\beta$ : 短対角線長さ

ビッカース圧子押し込みによるクラックの生成には， Tensometer 社製小型引っ張り試験機を使用し，荷重 30 $\mathrm{kg}$ ，印加速度 $3 \mathrm{~kg} / \mathrm{s}$ で行った。

焼結体の密度測定は,アルキメデス法によって行った.

\section{3. 結果と考察}

アルミナとw-BN 混合物の理論密度に対する焼結体 の相対密度を求めた，超高圧焼結体の密度は，99\%以 上であった. 焼結体を真空中, $1300^{\circ} \mathrm{C}$ で熱処理した場合, w-BN はすべて黒鉛類似の結晶構造 g-BN に変化するの で，真空熱処理した焼結体の相対密度はアルミナ-g $\mathrm{BN}$ 複合体の理論計算密度值に対して求めた。焼結体の 相対密度を図 1 に示す．図 1 に見られるごとく，真空熱 処理した焼結体の密度は $90 \%$ 程度まで低下しているも のがあった。また個々の測定值にも大きなばらつきが あった。これは熱処理によって焼結体内部に多数のク ラックが入ったためと考えられる。

原料粉末混合後の X 線回折像には，窒化ホウ素とし てはウルツ鉱型のみが同定されたが，焼結後は黒鉛型， ウルツ型，閃垔鉛鉱型いずれも同定されなかった。これ は衝撃合成 w-BN が高温高圧下で非晶質化したため X 線回折像に現れなかったためと考えられる.熱処理後は, 黒鉛型のみが同定された。Akashi らのw-BN 単体の高 温高圧実験によると， $6 \mathrm{GPa} ， 1300^{\circ} \mathrm{C}$ では一部が閃亜 鉛鉱型に相転移することが報告されている ${ }^{5}$. w-BN 単 体の場合とアルミナとの混合物とでは，ウルツ鉱型 $\rightarrow$ 閃 亜鉛鉱型相転移の臨界温度と圧力は異なると考えられる が今回の実験条件はこの相転移の途上にあったためこの ような非晶質化が起きたと考えられる.

焼結体破面の走査型電子顕微鏡 (以下 SEM) 写真を 図 2 に示した.アルミナ単体の焼結体破面の SEM 観察 によると, 原料粉末粒径 $0.2 \sim 0.3 \mu \mathrm{m}$ のものが $10 \sim 15$ $\mu \mathrm{m}$ に成長しているのに対し，w-BN を加えたものは 2 $\mu \mathrm{m}$ 程度に粒成長が抑制されていることが分る。

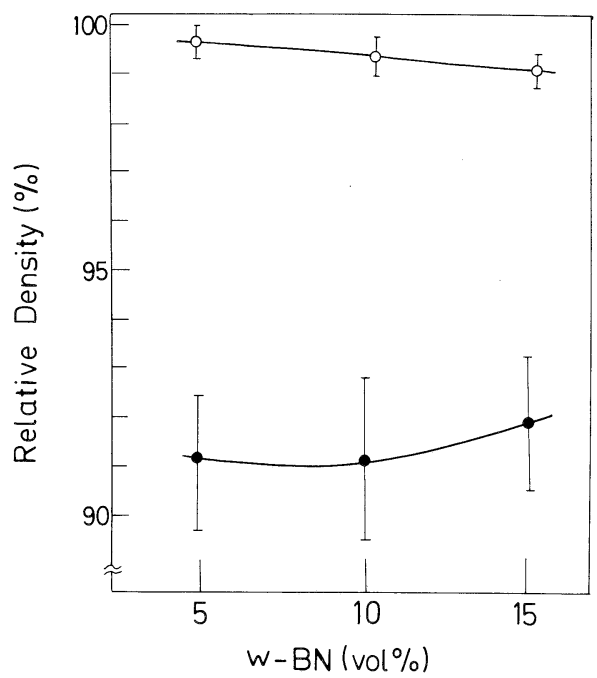

Fig. 1. Apparent density of $\mathrm{Al}_{2} \mathrm{O}_{3}-\mathrm{w}-\mathrm{BN}$ compacts obtained by very high pressure sintering at $6 \mathrm{GPa}$ and $1300^{\circ} \mathrm{C} ;(\bigcirc)$ as-sintered compacts and (O) compacts heat-treated in vacuum of $10^{-3}$ Torr at $1300^{\circ} \mathrm{C}$. 


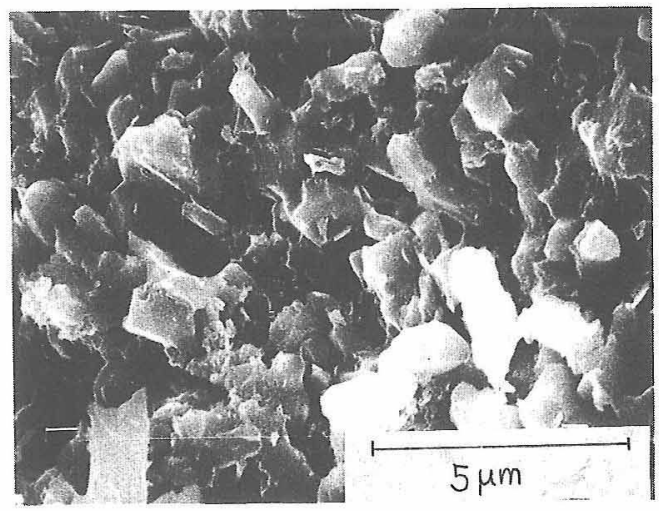

(a)

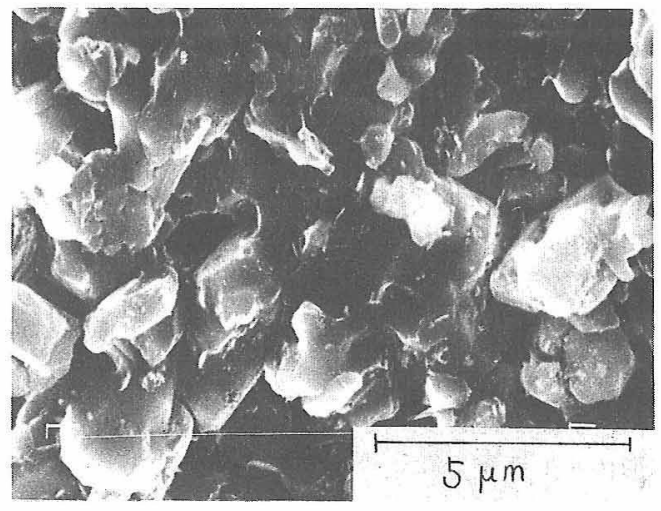

(b)

Fig. 2. SEM micrographs of fracture surface of compacts sintered at $6 \mathrm{GPa}$ and $1300^{\circ} \mathrm{C}$, and heat-treated in vacuum of $10^{-3}$ Torr at $1300^{\circ} \mathrm{C}$ for $6 \mathrm{~h}$.

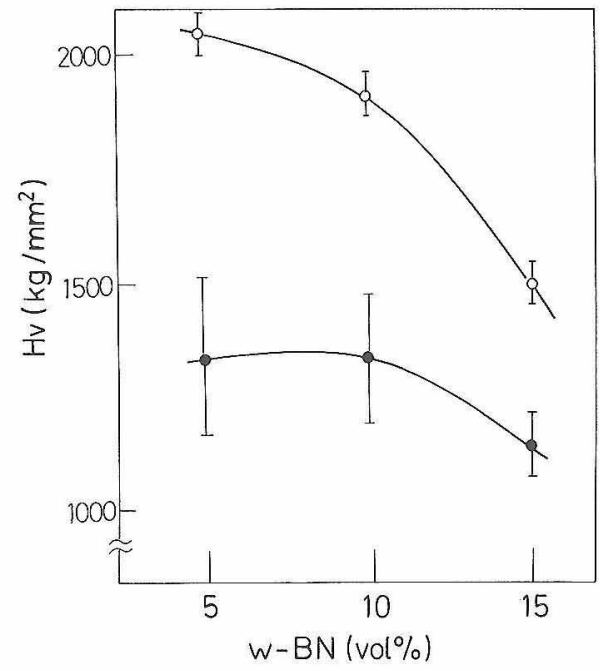

Fig. 3. Vickers hardness of $\mathrm{Al}_{2} \mathrm{O}_{3}-\mathrm{w}-\mathrm{BN}$ compacts obtained by very high pressure sintering at $6 \mathrm{GPa}$ and $1300^{\circ} \mathrm{C} ;(\bigcirc)$ as-sintered compacts and (O) compacts heat-treated in vacuum of $10^{-3}$ Torr at $1300^{\circ} \mathrm{C}$.

焼結体の微小硬さ $\left(H_{\mathrm{v}}\right)$ の測定結果を図 3 に示した。 アルミナ-w-BN 系超高圧煍結体の微小硬さは, w-BN の添加とともに減少する．焼結体の真空熱処理によって 硬さは20３0\% 減少した。

$K_{1 \mathrm{c}}$ の測定結果を図 4 に示した，報告されているアル ミナ焼結体の $K_{1 c}$ の值は $4 \sim 4.5 \mathrm{MN} / \mathrm{m}^{3 / 2}$ である ${ }^{6)}$. wBN を添加した超高圧焼結体の $K_{1 \mathrm{c}}$ は w-BN が $10 \%$ で 極大を示した。真空熱処理した焼結体の $K_{1 \mathrm{c}}$ は末処理の ものに比べ約 $30 \%$ 減少していることが分る，著者らは アルミナーダイヤモンド系において，今回同様の熱処理 条件で実験を行いダイヤモンドを $10 \%$ 添加したものに ついて $K_{1 \mathrm{c}}$ が $45 \%$ 向上したことを報告した 化ホウ素添加での実験では靶性向上の点で逆の結果と



Fig. 4. Critical stress intensity factor $K_{1 \mathrm{c}}$ of $\mathrm{Al}_{2} \mathrm{O}_{3}-\mathrm{w}$ $\mathrm{BN}$ compacts obtained by very high pressure sintering at $6 \mathrm{GPa}$ and $1300^{\circ} \mathrm{C} ;(\bigcirc)$ as-sintered compacts and (O) compacts heat-treated in vacuum of $10^{-3}$ Torr at $1300^{\circ} \mathrm{C}$.

なった。この理由としての次のことが考えられる。衝撃 合成 $\mathrm{w}-\mathrm{BN}$ は，真空中， $600^{\circ} \sim 700^{\circ} \mathrm{C}$ で黒鉛型に相転移 を始めるが，ダイヤモンドは真空中 $1000^{\circ} \sim 1100^{\circ} \mathrm{C}$ で黒 鈶に転移する。この際 w-BN はマルテンサイト型変態 により急激に $\mathrm{g}-\mathrm{BN}$ に変わるのに対し，ダイヤモンドで は拡散を伴うゆっくりとした変態が起こる。このときの 体積膨張は窒化ホウ素，炭素ともに $50 \%$ 程度である。 いま分散粒子を含むアルミナ焼結体として同一モデルを 仮定してみる。w-BN を含む焼結体では，ダイヤモンド を含む焼結体とは異なり，アルミナが塑性変形しにくい 低温で急激に分散粒子が膨張する。このとき発生する大 きな応力を母相は変形によるだけでは吸収しきれず，ク ラックを生じてしまう。このクラックの生成により破噮 
靶性が低下したと考えられる。

\section{4. 総 括}

本報告では，アルミナ-w-BN 系複合材料について超 高圧焼結を行い, その密度, 硬さ, 破壊䩲性を測定し, $\mathrm{X}$ 線回折及び SEM 観察を行った.この結果，アルミナ -ダイヤモンド系で成功した応力誘起微小クラック生成 による勒性の向上がアルミナ-w-BN 系では認められず, 靯性は逆に低下した。これは BN と炭素の相転移温度 の差と転移機構の違いによると考えられる.

謝辞 本研究に関して有益な助言を賜った東京工業大学 工業材料研究所の近藤建一助教授, 薄葉 州助手に深く感謝の
意を表します。また w-BNを提供して頂いた日本油脂 (株)の荒 木正任氏に厚く御礼申し上げます。

\section{文献}

1) T. Noma and A. Sawaoka, J. Mater. Sci. (in press).

2) T. Noma, A.Sawaoka, J. Marion and A. G. Evans, in "Advances in Ceramics", Proc. of Zirconia, 1983 (in press).

3) B. R. Lawn, A. G. Evans and D. B. Marshall, J. Am. Ceram. Soc., 63, 574-81 (1980).

4) D. B. Marshall, T. Noma and A. G. Evans, ibid., 65, C-175 (1982).

5) T. Akashi, A. Sawaoka, S. Saito and M. Araki, Japan J. Appl. Phys., 5, 891-92 (1976).

6) B. Mussler, M.V. Swain and N. Claussen, J. Am. Ceram. Soc., 65, 566-72 (1982). 